\title{
Study on Middle Vocational Chinese Teaching and Professional Course Teaching Practice
}

\author{
Baoqin LI \\ Weifang University of Science and Technology \\ Shouguang, Shandong, 262700 China
}

\begin{abstract}
In recent years, middle vocational Chinese teaching is in difficulty, and it is mainly "knowledge-based" mode, and general teaching color is strong, which cannot reflect middle vocational education feature, ignoring the social economic function of vocational education. This paper takes two middle vocational colleges of Shandong Shouguang as the research object, studying the reasons and countermeasures of middle vocational Chinese teaching phenomenon, in order to improve the middle vocational students' interest in learning Chinese, cultivating their occupation morality and aesthetic taste and other comprehensive Chinese ability, in order to cultivate more compound talents for the society.
\end{abstract}

Keywords-middle vocational; Chinese teaching; professional teaching; combination;

\section{INTRODUCTION}

This paper takes Shandong Shouguang two national key middle vocational colleges of 2011 financial accounting, mechanicals, computer, chemicals, vegetables and flowers of five majors of students as the research object, analyzing the middle vocational Chinese teaching status reason, and it explores improving middle vocational Chinese teaching quality method. This paper adopts the questionnaire method, giving out 200 pieces of questionnaires and recovering 182 pieces. Through the analysis, it finds the existing problems of middle vocational Chinese teaching, and combined with practice teaching, it tries to find practical solutions.

\section{StATUS ANALYSIS}

\section{(1) Students' "Learning” Status}

\section{1) Insufficient Motivation and Lacking of Learning Interest}

At present, most middle vocational students' learning is in middle and lower level. With our province implementing high school extension system in recent years, the overall level of student source has the reducing trend. Many students go to vocational colleges to learn a skill, and they need useful "fast food" learning, without needing "high-grade feast". So they lack of corresponding learning interest for Chinese course.

\section{2)Learning Methods Are Not Scientific.}

Lacking of good learning habits and learning method makes middle vocational students lazy, strong dependence, inactive learning and not previewing before class, not review and summarizing after class, without taking notes in class, or they don't know how to listen to class.

\section{3)More Professional Course and Less Culture Foundation Class}

Due to its vocational feature, vocational college students decide the learning motivation, which has more social factor, since entering vocational college, and it is related to many social occupations. Many students go to middle vocational colleges to learn a skill, thus, in learning, it should grasp vocational skills, learn practical operation ability and care about vocational development trend and employment trend.

(2) Teachers" "Teaching” Status

\section{OLD TEACHING CONCEPT AND WiTHOUT VOCATIONAL FEATURES}

Middle vocational teachers mostly use traditional teaching methods, and the classroom reflection is "teachers teach and students listen" of this simple knowledge transfer process, and teachers are the classroom master, and students are "knowledge storage base". Many teachers are used to chewing article, chapter, sentence and discourse knowledge to students, and then it has the status of teachers focusing more on knowledge teaching and less ability formation process, and it can not combine with vocational school feature, highlighting vocational features.

\section{BORING TEACHING CONTENT AND IGNORING STUDENTS' INTEREST}

Interest is the best teacher, and the largest interest of middle vocational students is related with its professional relevant knowledge. But in practice, most Chinese teachers echo what the books say, and they rarely determine corresponding teaching goal and teaching content according the actual situation of different majors. Even sometimes they complement some extracurricular knowledge to students, they can just cause students' attention in a short time.

\section{Single Teaching Method And Without PROFESSIONAL FEATURES}

Most Chinese teachers are used to one book, one pen and one mouth teaching mode in teaching. In designing teaching process, teachers are limited to teaching content 
and its knowledge system in organizing classroom teaching, ignoring the analysis of students' age, major and interest. In class, they try to makes students into their preconceived situation.

\section{Countermeasure Research}

"Vocational education should take ability as the oriented teaching guidance ideology, major setting and professional development as the social and economic demand as the leading, starting from labor market analysis and vocational post analysis, with scientific and reasonable mode." These principles tell us that middle vocational education and teaching should take students' ability as the orientation, and vocational knowledge quality and vocational technical ability education are the two goals of vocational education.

\section{(1)Updating Teaching Goal}

The hierarchical teaching method is to fabricate different teaching goals for the current knowledge structure, age feature, intelligence level and non-intelligence factor difference of teaching objects, and it proposes different teaching requirements, implements different teaching content and adopts different teaching methods, in order to mobilize the learning enthusiasm of each student maximumally.

\section{(2)Enriching Teaching Content}

\section{1) Strengthening Oral Communication Training}

In classroom teaching, we should let students learn to speak. In Chinese teaching of Weifang Science and Technology College for three years, we are implementing "lecture before class" plan, for different majors, fabricating different topics, and the topics are mutually fabricated by teachers and students. We can comment the social phenomenon and also we can summarize our study life status, or make film or book statement review. By taking financial major and guide major as an example, we make different outlines for different majors.

"Lecture before class" outline

\begin{tabular}{|c|c|}
\hline Finascial majoe & Gride major \\
\hline 1Self-inrodyetise & 15elf-inrobostion \\
\hline 2. Introbseing a certain protsest & $\begin{array}{l}2 \text { Ienrobucting my } \\
\text { bomesome }\end{array}$ \\
\hline $\begin{array}{l}\text { 3. Ierrotocting a book of a film } \\
\text { that jos read }\end{array}$ & $3 . \mathrm{My}$ frived \\
\hline 4.My dream & $4 \mathrm{M} / y$ dresm \\
\hline $5 \mathrm{Mly}$ favorite job & SMgy favorite job \\
\hline 6. Shoping(convumptisa) feeling & $\begin{array}{l}\text { 6Iarodveing a cerain } \\
\text { place bat yos wish }\end{array}$ \\
\hline $\begin{array}{l}\text { 7.Adractage aod dicadracage of } \\
\text { online sbopping }\end{array}$ & $\begin{array}{l}\text { 7My favorite sad(oe } \\
\text { celebrity) }\end{array}$ \\
\hline $\begin{array}{l}\text { 8.Tating about indinitsal } \\
\text { colativation }\end{array}$ & 8. Tatking about food \\
\hline
\end{tabular}

\section{2) Strengthening Practical Writing Teaching}

For example, we take "climbing Mount Tai in the rain" in "appreciating natural masterpiece" unit, and we design a practical writing teaching plan for guide major students. Practical writing teaching plan in "climbing Mount Tai in the rain"

\begin{tabular}{|c|c|}
\hline Training abiling & Teaching process and acrangmentat \\
\hline 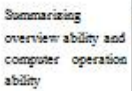 & 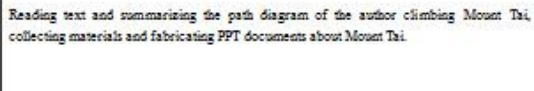 \\
\hline $\begin{array}{l}\text { Pracival meating } \\
\text { gribs words }\end{array}$ & 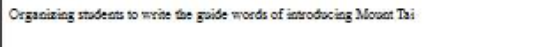 \\
\hline $\begin{array}{l}\text { Oral expersise } \\
\text { abdiny }\end{array}$ & 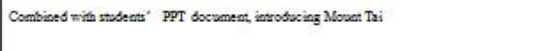 \\
\hline $\begin{array}{l}\text { Practical wring } \\
\text { motise, phan oral } \\
\text { expression }\end{array}$ & 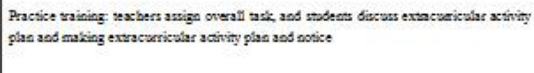 \\
\hline $\begin{array}{l}\text { Practisal ering } \\
\text { semenary }\end{array}$ & 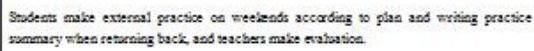 \\
\hline
\end{tabular}

\section{3) Professional Culture Association and Introduction}

Chinese is the basic traditional subject with a long history, and only highlighting professional culture can attract middle vocational students' interest, for example, in Chinese teaching process, teachers can introduce competition incentive mechanism for students of marketing and industrial and commercial management major, which makes students study in pressure and pleasant atmosphere. We can refer to online resource and conduct television teaching, introducing the programs of similar "meridian letters", "job exchange", "challenging host", "touching Chinese awards ceremony", "exploration and discovery" and other vivid and beautiful programs into classroom.

\section{(3) Reforming Teaching Methods}

In the survey, middle vocational students long for lively and vivid and relaxing and effective language learning classroom, which requires us to reform the traditional Chinese teaching mode, in order to gradually create the Chinese teaching method of taking innovation as the mission and taking vivid and practicality as the goal.

\section{1) Arousing Learning Method}

We should skillfully lead, for different majors' different hobbies, making different teaching goals, to attract students to produce interest for teaching content, such as the article "Lin Daiyu entering Jia House, requiring students of guide major to make PPT according to text content. In the picture display process, as a guide, you can lead others into Jia House, to introduce the character relationship and architecture layout of Jia House to others. For students of art design major, it requires them to describe the architecture layout and character clothing of Jia House based on reading the article.

\section{2)Scenario Simulation Method}

In teaching practice, there are a variety of scenario creation modes, which can associate students' daily life and 
experience, and also simulate social life communication situation, and we can use audio and video pictures for mobilizing.

\section{3)Application of Media Means}

In middle vocational Chinese teaching, it can use multi-media modern education technology means and help students to collect materials for preview, in order to provide full background knowledge for students and lay the foundation.

\section{4)Expanding Teaching Method}

The extension of Chinese learning is equal to life extension. The practicality and application of vocational education determine that Chinese teaching can go out of classroom, and through the extension and expanding of extracurricular activities, it can implement open teaching, in order to realize the combination of Chinese ability and vocational ability.

\section{5) Collaborative Teaching}

"Collaborative teaching refers to that, in order to achieve a common teaching goal, professional teachers and Chinese teachers teach in their own classes, leading students to happily study the professional knowledge and Chinese knowledge." For example, when we teach "dish naming" this class, we can use the power of professional teachers, conducting the mutual corresponding and organic combination of Chinese knowledge and professional knowledge, making ability training in the whole teaching process, with a good effect. The collaborative teaching design of "dish naming" course is as shown in the following chart.

"Collaborative" teaching design plan of "dish naming" course

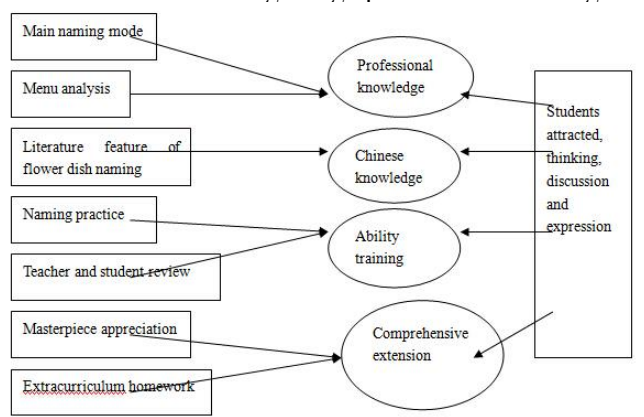

Collaborative teaching makes Chinese teaching and professional teaching become win-win. But in this process, Chinese teachers and professional teachers should cooperate closely, providing materials by Chinese teachers and professional teachers form relevant practice database, consisting of a whole set of system. So the collaboration of professional teaching and Chinese teaching will not be in form, without false or demonstrative show. Also, it requires teachers to grasp the "degree" problem, which should not be strong and hard, and it should be proper according to the teaching materials, and it doesn't need to combine with each piece, avoiding the pure "music history" and "art history" of middle vocational Chinese.

\section{References}

[1] Bruno. Education process, Education Science Press, 1982.

[2] Sue Homelinsky. Suggestions to teachers, Education Science Press, 1984.

[3] Ye Shengtao. Ye Shengtao education collection, People' Education Press, 1994.

[4] Cheng Hongbing. Humanity thought and practice in Chinese teaching, Chinese Railway Press, 1996.

[5] Wang Shangwen. Theory of language sense[M]. Shanghai Education Press, Shanghai, 2000. 